\title{
Influence of Brush Control on White-tailed Deer Diets in North-Central Texas
}

\author{
DEE A. QUINTON, RONALD G. HOREJSI AND JERRAN T. FLINDERS
}

\begin{abstract}
Botanical composition of white-tailed deer fecal pellets from untreated and brush-controlled areas of the Texas Rolling Plains was studied by microscopic analysis. Deer showed a marked preference for 11 of 54 plant species selected as food from a total of 250 identified on the study area. The bulk of the diet was comprised of mistletoe on non-brush control areas and of pricklypear on brush-controlled areas. Similarity indices relating habitat across diets as well as diets across a habitat indicated that several habitats had preferred foods removed. These habitats also had low populations of deer. Brush control involving limited removal of noxious species affected dietary selection of deer but did not appear to affect overall deer usage of the habitats studied.
\end{abstract}

Ever-increasing costs and low returns to the ranching industry in Texas has made the noxious brush problem an item of major concern. With more than $50 \%$ of Texas rangeland covered with brush too dense for optimal livestock production and an additional 23\% moderately infested (Smith and Rechenthin 1964), brush control has become a common practice. This control has been used mainly for increasing grass and livestock production, with little effort expended to document the effects of brush control on wildlife populations.

The value of wildlife resources becomes increasingly important to land managers when leased trespass rights for hunting compare favorably with economic returns from livestock production (Ramsey 1965). Since habitat management is of paramount importance for sustained optimal production of game animals, land managers should carefully scrutinize brush control practices that will affect wildlife populations. The objectives of this research were to determine the importance of brush species in the diet of white-tailed deer (Odocoileus virginianus), to ascertain decr dicts in various brush control habitats of north-central Texas, and to compare the similarity of deer diets to available forage in deer habitats.

\section{Study Area}

The study was conducted on 17,000 ha of native grassland located near the juncture of Haskell, Shackleford, and Throckmorton counties in the Rolling Plains of north-central Texas. The area, traversed by the Clear Fork of the Brazos River, is typified by varying topography, ranging from nearly flat plains to rough broken terrain along the river. Differences in elevation $(152 \mathrm{~m})$ between valley bottom areas and adjacent ridges limit mechanical brush control practices to the more

\footnotetext{
The authors are research scientist, Agriculture Canada Rescarch Station, Kamloops, British Columbia, V2B 8A9; biologist, Arizona Game and Fish Department, Research Division, 2222 West Greenway Road, Phoenix, Arizona 85023; and associate professor. Department of Botany and Range Science, Brigham Young University, Provo, Utah 84602.

This report is a contribution of the College of Agricultural Sciences. Texas Tech University, Publications Number T-9-180.

Manuscript received January 1, 1978
}

level areas. Soils are deep on level areas and shallow with limestone outcroppings along drainage channels. Precipitation averages $69 \mathrm{~cm}$ per year (Korschgen 1967).

Vegetational communities in the area included 250 different species of plants. Valley bottom habitat had large honey mesquite (Prosopis glandulosa), pecan (Carya illinoensis), and soapberry (Sapindus saponaria) as the most prevalent trees. Pricklypear cactus (Opuntia macrorhiza) and tasajillo (Opuntia leptocaulis) were prevalent in the midstory. Numerous grasses and forbs made up the understory. Upland vegetation differed in that honey mesquite was dominant in the overstory.

Texas wintergrass (Stipa leucatricha), buffalograss (Buchloe dactyloides), sand dropseed (Sporobolus cryptandrus), slim tridens (Tridens muticus), vine mesquite (Panicum obtusum), sideoats grama (Bouteloua curtipendula), and threeawns (Aristida spp) were common grases. Common torbs included pelotazo (Abutilon incanum), western ragweed (Ambrosia psilostachya), wine cup (Callirhoe involucrata), spectacle pod (Dithyrea wislizensii), spreading sida (Sida filicaulis), and silverleaf nightshade (Solanum elaeagnifolium). More prevalent browse species included ironwood (Bumelia lanuginosa), mistletoe (Phorodendron villosum), polecat bush (Rhus aromatica), and littleleaf sumac ( $R$. microphylla).

Brush control on the study area ranged from no treatment to an attempt at total removal of brush and trees. Habitats studied included an untreated upland; an upland from which all trees and brush had been removed with a crawler bulldozer in 1972; an upland treated with $2,4,5-\mathrm{T}$ and chained in 1957, resprayed in 1972; an upland treated with 2,4,5-T in 1964; an untreated valley bottom area; and a valley bottom area where mesquite and cacti had been selectively bulldozed in 1964.

The smallest habitat was 1,200 ha in size, an area which could accommodate 4.7 separate home ranges of white-tailed deer.

\section{Methods}

Percent cover and frequency of vegetation was taken along two randomly located $250-\mathrm{m}$ line transects in each habitat. Four $8 \times 15 \mathrm{~m}$ intensive sampling units, located $35 \mathrm{~m}$ apart, along each line were subdivided into four $2 \times 15-\mathrm{m}$ belts to obtain cover and frequencies of trees and shrubs. Data for grasses, forbs, succulents and small shrubs were obtained from three $30 \times 30-\mathrm{cm}$ quadrats in each belt.

A microhistological examination of decr feces was used to determine diets of deer. We collected 10 pellet groups of fresh feces from the center of each habitat during July, October, December (1971), and April (1972). Duplicate slides were prepared according to methods outlined by Sparks and Malechek (1968), Ward (1970), Flinders and Hansen (1972), Baumgartner and Martin (1939), and Baker and Wharton (1952). Ten fields per slide were examined at 100 magnification to obtain an estimate of the relative frequency of food items in deer diets (Free et al. 1971; Hansen and Reed 1975). We converted relative frequencies to particle densities (Fracker and Brischle 1944), and thence to relative percent dry weight of each food item identified in deer feces (Sparks and Malechek 1968). Individual food items were 
identified by comparing histological features identified in fecal fragments to a reference slide collection prepared from plants collected on the study area (Davies 1959; Brusven and Mulkern 1960; Storr 1961).

Kulczynski's mathematical expression of similarity (Oosting 1956) was used to relate similarities among habitats and diets.

Population estimates of the deer herd were obtained using a spotlight from a moving vehicle after dark.

\section{Results and Discussion}

\section{Habitats}

Table 1 shows the degree of similarity among habitat overstory and understory vegetation. The bulldozed valley and untreated unpland were most similar in overstory to the untreated valley bottoms, whereas the understory of the sprayed upland and untreated valley hottoms most closely resembled that of the untreated upland habitat. The generally low similarities indicate the uniqueness and diversities of the habitat communities involved.

Honey mesquite was the most prevalent species of tree on the untreated river bottoms ( $55 \%$ relative frequency, 50\% cover). Ironwood and hackberry (Celtis occidentalis) had relative frequencies of $22 \%$ and $16 \%$ respectively. Pecan, soapberry, walnut (Juglans sp), and buckeye (Unganadia speciosa) were scattered throughout the area. Tasajillo and mistletoe, which was parasitic to mesquite, were common with relative frequencies of $71 \%$ and $16 \%$, respectively. Grasses accounted for $56 \%$ of the relative frequency and $70 \%$ of the cover of the understory.

Bulldozed valley bottoms had a more park-like appareance than untreated valley bottoms. Ironwood predominated in the overstory ( $44 \%$ relative frequency, $5 \%$ cover), mesquite was reduced to $32 \%$ relative frequency, and soapberry had increased to $16 \%$ relative frequency. Lotebush (Ziziphus obtusifolia) at $32 \%$ relative frequency had replaced tasajillo as the predominant shrub. Mistletoe had been reduced in prevalence in direct proportion to the reduction in Mesquite. Grass had a relative frequency of $60 \%$, making up $56 \%$ of the ground cover in the understory.

The overstory of the untreated upland was primarily mesquite, hackberry and ironwood with relative frequencies of $41 \%, 18 \%$, and $13 \%$ respectively. Elbowbush (Forestiera pubescens) and mesquiteparasitic mistletoe were prevalent browse species (relative frequencies of $7 \%$ and $31 \%$ respectively). Grasses and forbs were equally distributed. Pricklypear accounted for $5 \%$ of the total ground cover.

The bulldozed upland habitat was an open grassland, with grasses making up $55 \%$ of the relative frequency and $60 \%$ of the cover of the understory. Mesquite seedlings were the principal woody species present, with $28 \%$ frequency and $<1 \%$ cover. Pricklypear and mistletoe were reduced to $1 \%$ of the total ground cover.

Mesquite was reinvading the sprayed upland site, having a relative frequency of $38 \%$ but accounting for only $3 \%$ of the ground cover. Ironwood catclaw (Acacia sp), elbowbush, hackberry, buckeye and lotebush all had relative frequencies about $5 \%$ and mistletoe had a relative frequency of $19 \%$. Grasses, with a relative frequency of $58 \%$, were twice as prevalent as forbs. Pricklypear was the predominant midstory vegetation, making up $8 \%$ of the total cover.

Grasses were most prevalent on the sprayed-chained-resprayed site, accounting for $60 \%$ relative frequency and $87 \%$ of the ground cover. Mesquite and lotebush were common, with relative frequencies of $34 \%$ and $28 \%$, respectively. However, these shrubs were young plants, as each contributed only $1 \%$ of the total cover.

\section{Diets}

Fifty-four (Table 2) of the 250 species of plants identified on the study area were ingested by white-tailed deer. Of the 54, 11 made up the bulk of their diet (Table 3).

Mistletoe was the single most important food, accounting for $35 \%$ of the over-all diet. Mistletoe was the prevalent dietary item on untreated habitats. Its prevalence in diets of deer decreased in relation to its decreased occurrence in the habitat. Mistletoe made up 80-90\% of the relative dry weight (RDW) of winter and spring diets respectively, on untreated valley bottom, as well as $70 \%$ RDW of the winter diet on bulldozed valley bottom habitat. Mistletoe in spring diets in bulldozed valley bottoms declined to $19 \%$ RDW when ironwood browse increased in prevalence in the diet. Mistletoe usage was only $9 \%$ to $17 \% \mathrm{RDW}$, respectively, of the summer and fall diets of deer on treated valley bottom habitats and $1 \%$ to $6 \%$ RDW, respectively, of the summer and fall diets in untreated valley bottom habitats. It was also prevalent in the winter and spring diets on upland habitats. Ingestion of mistletoe was greatest on the sprayed upland site, where its frequency in the habitat was only about one-half that of the untreated upland site. High incidence of mistletoe in diets was also noted in the sprayed-chained-resprayed and the bulldozed upland habitats. This prevalence in the diet from habitats having a low frequency of hot plants (honey mesquite) can partially be explained by canopy structure of the plant community. The overstory in treated upland habitats consisted of short regrowth and new plants with the foliage readily accessible to deer. Mistletoe in this canopy was thus easily accessible to browsing deer.

Pricklypear was the second most important food item, accounting for $18 \%$ RDW of the total diet. Consumption of pricklypear was greatest on areas which had experienced more intense efforts at brush control (bulldozing and sprayed-chained-resprayed). Pricklypear was most prevalent in diets in bulldozed valley bottom habitats during summer and fall, when it made up $18 \%$ and $60 \%$ RDW, respectively, of the diet. With the exception of the fall diet (20\% RDW) pricklypear was relatively unimportant in untreated valley bottom habitats. Pricklypear on bulldozed upland and sprayed upland sites made up $32 \%$ and $26 \%$ RDW, respectively, of fall diets; $27 \%$ and $18 \%$ RDW, respectively, of summer diets; and small amounts of spring and winter deer diets. In the absence of other available

Table 1. Symmetrical matrices of similarity indices (\%) and Standard Errors of plant communities in various habitat types in north-central Texas.

\begin{tabular}{|c|c|c|c|c|c|c|}
\hline Treatment & $\begin{array}{c}\text { Untreated } \\
\text { valley bottom }\end{array}$ & $\begin{array}{c}\text { Dozed } \\
\text { valley bottom }\end{array}$ & $\begin{array}{l}\text { Untreated } \\
\text { upland }\end{array}$ & $\begin{array}{l}\text { S-C-S } \\
\text { upland }\end{array}$ & $\begin{array}{l}\text { Sprayed } \\
\text { upland }\end{array}$ & $\begin{array}{l}\text { Dozed } \\
\text { upland }\end{array}$ \\
\hline Untreated valley bottom & +2 & $36.4 \pm 4.4$ & $37.7 \pm 0.3$ & $15.7 \pm 5.1$ & $27.3 \pm 1.9$ & $22.6 \pm 0.2$ \\
\hline Bulldozed valley bottom & $19.5 \pm 2.5$ & & $21.2 \pm 1.1$ & $15.6 \pm 6.7$ & $22.8 \pm 1.4$ & $17.5 \pm 0.8$ \\
\hline Untreated upland & $13.4 \pm 0.7$ & \multicolumn{3}{|c|}{$9.4 \pm 1.1$ understory overstory $11.8 \pm 3.5$} & $35.1 \pm 0.8$ & $20.4 \pm 1.8$ \\
\hline S-C-S upland & $13.6 \pm 1.4$ & $15.9 \pm 1.4$ & $15.8 \pm 1.4$ & & $16.7 \pm 4.0$ & $26.0 \pm 5.6$ \\
\hline Sprayed upland & $18.9 \pm 3.2$ & $14.0 \pm 2.0$ & $20.1 \pm 2.8$ & $19.9 \pm 5.2$ & & $18.0 \pm 1.9$ \\
\hline Bulldozed upland & $15.1 \pm 2.9$ & $10.8 \pm 1.5$ & $18.8 \pm 5.2$ & $21.3 \pm 6.2$ & $21.6 \pm 4.0$ & \\
\hline
\end{tabular}


Table 2. Percent relative dry weight of food items in the diet of white-tailed deer in the Rolling Plains of north-central Texas.

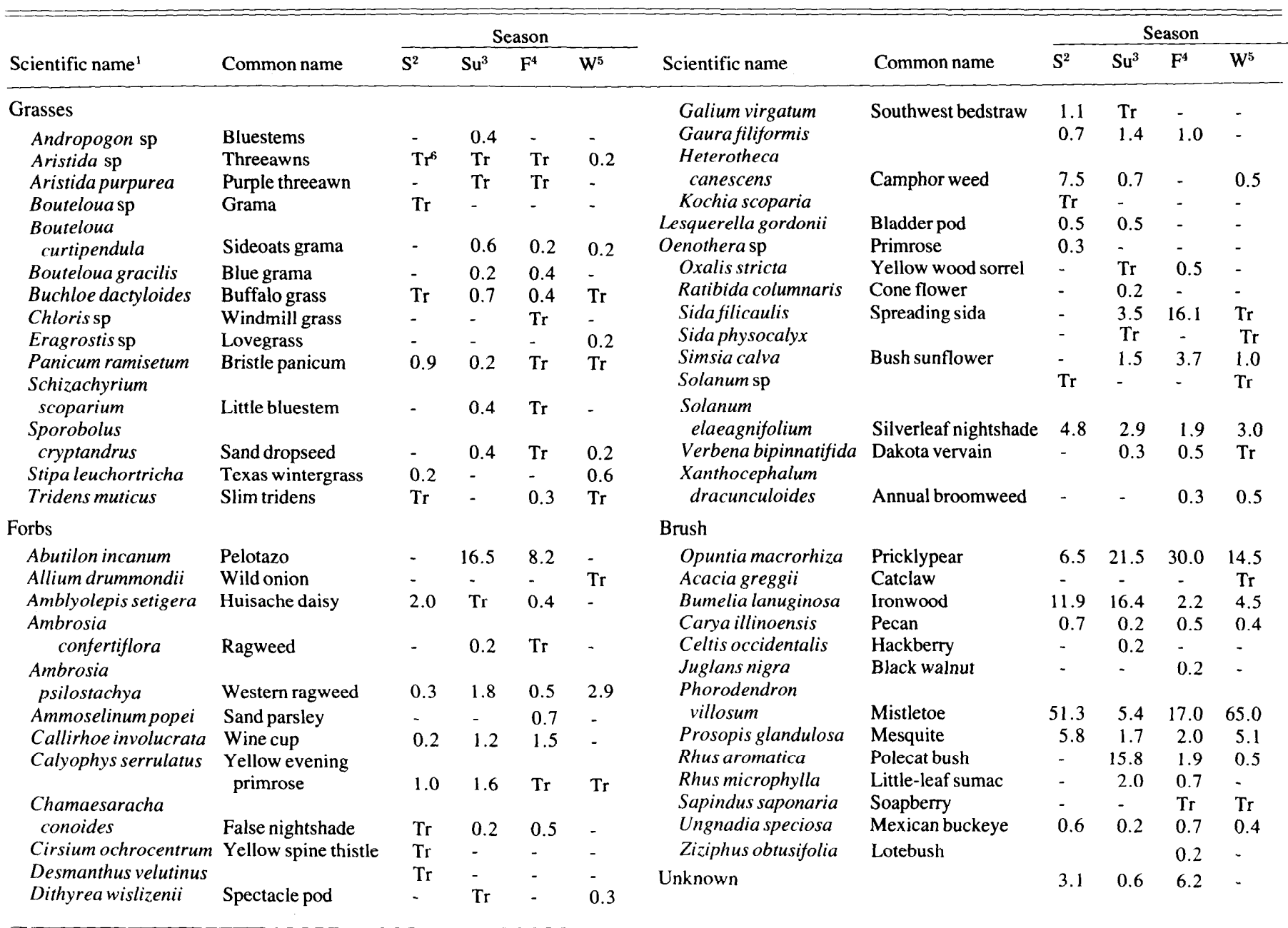

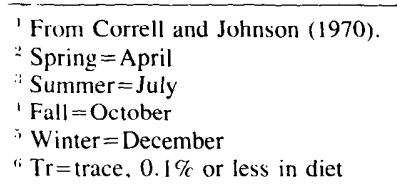

browse, pricklypear was the staple food of deer in the sprayedchained-resprayed habitat. This is readily apparent when $94 \%$, $75 \%, 82 \%$ and $28 \%$ RDW's of the fall, winter spring and summer diets respectively, consisted solely of pricklypear fruits and pads. Usage of this forage in untreated upland habitats was slight, ranging from a low of $0.4 \%$ RDW of the fall diet to $4 \%$ RDW of the spring diet.

Ironwood (9\% RDW of total diet) was extensively browsed in all habitats during the summer, and during the winter and spring on habitats where brush had been treated. It was the most

Table 3. Relative percent dry weights of major food items in yearly diets of white-tailed deer in various habitats in north-central Texas.

\begin{tabular}{|c|c|c|c|c|c|c|}
\hline & $\begin{array}{l}\text { Untreated } \\
\text { valley bottom }\end{array}$ & $\begin{array}{c}\text { Bulldozed } \\
\text { valley bottom }\end{array}$ & $\begin{array}{l}\text { Untreated } \\
\text { upland }\end{array}$ & $\begin{array}{l}\text { Sprayed } \\
\text { upland }\end{array}$ & $\begin{array}{l}\text { S-C-S } \\
\text { upland }\end{array}$ & $\begin{array}{l}\text { Bulldozed } \\
\text { upland }\end{array}$ \\
\hline Mistletoe & 50.9 & 23.2 & 33.9 & 44.6 & 7.6 & 16.8 \\
\hline Pelotazo & 9.3 & 0.4 & 4.0 & 17.2 & - & 4.3 \\
\hline Pricklypear & 5.9 & 20.8 & 2.1 & 12.1 & 69.8 & 29.7 \\
\hline Ironwood & 6.6 & 20.4 & 8.4 & 4.2 & 3.8 & 8.6 \\
\hline Polecat bush & 5.4 & 7.5 & 6.5 & 2.5 & $\mathrm{Tr}^{2}$ & 3.8 \\
\hline Mesquite & 1.7 & 2.5 & 8.8 & 2.8 & 1.1 & 0.7 \\
\hline Spreading sida & 2.3 & 3.0 & 10.4 & 3.0 & $\operatorname{Tr}$ & 8.9 \\
\hline Camphor weed & - & 0.6 & 6.9 & 1.0 & $\operatorname{Tr}$ & - \\
\hline Silverleaf nightshade & 3.3 & 1.5 & 3.0 & 0.9 & 8.3 & 1.3 \\
\hline Western ragweed & 1.3 & 2.6 & 0.3 & 0.6 & 0.4 & 7.0 \\
\hline Bush sunflower & 2.0 & 0.3 & 3.0 & 1.6 & - & 1.9 \\
\hline Other & 11.1 & 17.1 & 12.7 & 9.5 & 9.4 & 17.0 \\
\hline
\end{tabular}

\footnotetext{
S-C-S = Sprayed-chained-resprayed

$-\mathrm{Tr}=$ trace, items occurring as $0.1 \%$ or less
} 
prevalent dietary item in spring ( $48 \%$ RDW) and summer $(20 \%$ RDW) samples from the treated valley bottom habitat. It was second in importance (13\% RDW) for the winter diet and was not identified in fall diets in bulldozed valley bottom areas. Ironwood in untreated valley bottom sites made up $21 \%$ and $5 \%$, respectively, of the summer and winter diets but was unimportant as a deer food during the fall and spring. The use of ironwood by deer did not follow any general pattern in upland habitats. Ironwood made up $27 \%$ and $15 \%$ RDW respectively of the summer diet in the untreaed and bulldozed upland habitats, and $5 \%$ and $2 \%$ RDW of the fall diets of deer for the same areas. In addition it constituted 5\% RDW of the winter diet in the sprayed upland, and $15 \%$ and $5 \%$ RDW, respectively, of the spring diet of deer in the sprayed-chained-resprayed and sprayed upland habitats.

Polecat bush was a major food only in the summer diets of deer, when it accounted for $28 \%, 20 \%, 21 \%, 5 \%$ and $10 \%$, respectively, of the RDW ingested in the bulldozed valley, untreated upland, untreated valley, bulldozed upland, and sprayed upland sites. With the exception of the untreated upland habitats, 5\% RDW of the diet, polecat bush was only slightly browsed in fall and was not identified in spring or winter diets.

Forbs were important in diets of deer during the seasons of availability. Pelotazo was an important food in the sprayed upland habitat during the summer (44\% RDW) and fall (25\% $\mathrm{RDW})$. It was also ingested in moderate quantities in the untreated upland habitat (13\% RDW of diet), bulldozed upland (15\% RDW of diet), and in untreated valley bottom (21\% RDW of diet) habitat during summer. In addition, pelotazo made up $17 \%$ RDW of the fall diet in untreated valley bottoms. Spreading sida was ingested in fall while camphor weed (Heterotheca canescens) was a spring food in upland habitats. Silverleaf nightshade was ingested in all seasons, with the greatest use during summer, fall, and winter in untreated habitats and during spring in treated habitats. Bush sunflower (Simsia calva) was identified in fall diets, while western ragweed, with the exception of the dozed upland, was a winter food.

Honey mesquite twigs and pods were more frequent in the diet during winter and spring. However, mesquite pods were in short supply during these seasons, and were scarce on the study area. Deer season of use data does, however, agree with Krausman (1978), who reported mesquite in deer diets in Big Bend National Park during the periods May-June and AugustOctober, and with Anderson et al. (1965), who reported diets from the Guadalupe mountains in southeastern New Mexico. The prevalence of this food in the diet when it was not abundant in the habitat indicates that deer were actively seeking mesquite. Mesquite is additionally important to deer because it is the host plant of mistletoe, the major food item of white-tailed deer in this locality.

\section{Diet Comparisons}

The greatest similarity between deer diets on a particular habitat and the forage available in the habitat was $8.9 \%$ for the sprayed upland. Similarity indices (S.I.) between diets and habitats were generally in the range of $4 \%$ to $6.5 \%$ similarities. The highest values were comparisons among valley habitats to all diets from all habitats with the exception of the sprayedchained-resprayed habitat. The sprayed-chained-resprayed habitat compared to all diets, as well as the sprayed-chainedresprayed diet to all habitats, consistently produced the lowest values of similarity $(<3 \%)$. The dozed upland habitat compared to dozed upland diet also had a S.I. of little more than $3 \%$. These low S.I. indicate the severity of treatment to the habitat as explained below.

The low similarity indices between diets and associated forage available on the habitats and between diets across habitats indicate the degree of selectivity exhibited by deer. In perusing the similarity indices for diets with habitat it was noticed that low values were associated with brush control treatments which had heavily reduced preferred foods in the habitat. We further noticed that decreases in this S.I. were paralleled by deer population that would be found in an area (Table 4). Areas of low similarity between diet and habitat generally had the lowest populations of deer.

Table 4. Density estimates of white-tailed deer in various habitats in northcentral Texas.

\begin{tabular}{lr} 
Treatments & Deer/100 \\
\hline Untreated valley bottom & 7.3 \\
Untreated upland & 7.0 \\
Bulldozed valley bottom & 4.5 \\
Sprayed upland & 3.0 \\
Sprayed-chained-resprayed upland & 2.0 \\
Bulldozed upland &
\end{tabular}

Similarity indices among diets from different habitat types indicated that with the exception of the sprayed-chained-resprayed population, diets were generally about 65 to $69 \%$ similar. Diet comparisons between the sprayed-chained-resprayed population and other populations ranged from $29 \%$ to $45 \%$ similar, indicating that the forage complex on this habitat had been affected to the extent that white-tailed deer had been forced to markedly alter their diets (Table 3 ).

\section{Discussion}

Diets of white-tailed deer have been extensively studied at various seasons in numerous localities. Studies in Texas indicate that deer in south Texas are primarily grazers (Chamrad and Box 1968; Drawe 1968) while other studies indicate they are primarily browsers (Davis and Winkler 1968). Everitt and Drawe (1974) reported diets of deer varied in constituents and major composition in relation to individual community types on the same ranch. Our data support the findings of these later researchers.

Examination of fecal constituents showed that deer diets in the Texas Rolling Plains land resource area varied in relation to habitat manipulation. Mistletoe was predominant in deer diets on areas where trees infected with this parasite had been retained in the habitat. Pricklypear was the main food on areas which had experienced brush control measures aimed at elimination of brush species and hence elimination of mistletoe. In untreated habitat, browse was more prevalent in the diet, whereas cacti and forbs constituted the bulk of the diet in treated habitats.

Our data indicate that habitat manipulation which affects deer populations and habitat usage largely center around removal of preferred browse and the associated reduction in cover. Deer adapted to changes in habitat and food availability if adequate cover was retained in the habitat, while deer populations were reduced in areas with greatly reduced cover and a shortage of preferred foods. Selective removal of dense stands of brush with efforts to maintain mistletoe-infected trees and patches of pricklypear is recommended where deer populations are a part of land use plans for the Rolling Plains of Texas. 


\section{Literature Cited}

Anderson, A.E., W.A. Snyder, and G.W. Brown. 1965. Stomach content analysis related to condition in mule deer, Guadalupe Mountains, New Mexico. J. Wildl. Manage. 29:352-366.

Baker, E.W., and G.W. Wharton. 1952. An Introduction to Acarology. MacMillan and Co., New York. 465 p.

Baumgartner, L.L., and A.C. Martin. 1939. Plant histology as an aid in squirrel food-habit studies. J. Wildl. Manage. 3:266-268.

Brusven, M.A., and B.M. Mulkern. 1960. The use of epidermal characteristics for the identification of plants recovered in fragmentary condition from crops of grasshoppers. North Dakota Agr. Exp. Sta. Res. Rep. 3. 11 p.

Chamrad, A.D., and T.W. Box. 1968. Food habits of white-tailed deer in south Texas. J. Range Manage. 21:158-163.

Correll, D.S., and M.D. Johnston. 1970. Manual of the Vascular Plants of Texas. Texas Res. Found. Remner, Texas. $1881 \mathrm{p}$.

Davis, 1. 1959. The use of epidermal characteristics for the identification of grasses in the leafy stage. Brit. Grassl. Soc. J. 14: 7-16.

Davis, R.B., and C.K. Winkler. 1968. Brush vs. cleared range as deer habitat in southern Texas. J. Wildl. Manage. 32: 321-329.

Drawe, D.L. 1968. Mid-summer diet of deer on the Welder Wildlife Refuge. J. Range Manage. 21: 164-166.

Everitt, J.H., and D.L. Drawe. 1974. Spring food habits of white-tailed deer in the south Texas plains. J. Range Manage. 27:15-20.
Flinders, J.T., and R.M. Hansen. 1972. Diets and habitats of jackrabbits in northeastern Colorado. Range Science Dep. Sci. Ser. No. 12. Colorado State Univ., Fort Collins. 29 p.

Fracker, S.B., and J.A. Drischle. 1944. Measuring the local distribution of Ribes. Ecology 25:283-303.

Free, J.C., P.L. Sims, and R.M. Hansen. 1971. Methods of estimating dryweight composition in diets of steers. J. Animal Sci. 32:1003-1007.

Korschgen, L.J. 1967. Feeding habits and foods. pp. 137-198. In: B.H. Hewitt (ed.) The Wild Turkey and Its Managment. The Wildl. Soc., Washington, D.C. 589 p.

Krausman, Paul R. 1978. Forage relationships between two deer species in the Big Bend National Park, Texas. J. Wildl. Manage. 42:101-107.

Oosting, H.J. 1956. The Study of Plant Communities. W.H. Freeman and Co., San Francisco. $440 \mathrm{p}$.

Ramsey, C.W. 1965. Potential economic return from deer as compared with livestock in the Edwards Plateau Region of Texas. J. Range Manage. 18:247250.

Smith, H.N., and C.A. Rechenthin. 1964. Grassland restoration-the Texas brush problem. U.S. Dep. Agr. Soil Conserv. Serv. Temple, Texas

Sparks, D.R., and J.C. Malechek. 1968. Estimating percentages dry weight in diets using a microscopic technique. J. Range Manage. 21:264-265.

Storr, G.M. 1961. Microscopic analysis of feces, a technique for ascertaining the diet of herbivorous mammals. Aust. J. Bio. Sci. 14:157-164.

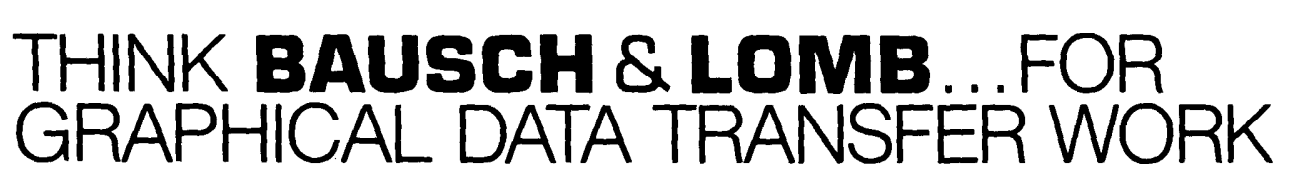

With a Bausch \& Lomb ZOOM TRANSFER SCOPE* instrument, you can quickly update a data base or prepare a special purpose thematic map without expensive data transfer, projection or darkroom equipment. These instruments work on the camera lucida principle that optically mix aerial photographs and data base without projection. Compare these performance features with what you are now using.

- Built-in scale and stretch correction systems compensate for photographic distortions. - Compact, lightweight design offers total portability. Can be used in a lighted office on any flat surface.

- Zoom control instantly matches photograph to data base scale.

- Accommodates all photographic formats including transparencies and prints (black and white or color). Stereo model (illustrated) helps you examine topographical and structural features. - Two models feature a photographic mode for permanent documentation.

\section{CALL US AT 716 338-6000}

And let a Bausch \& Lomb representative recommend the instrument that best meets your needs. Or, send coupon for illustrated literature.

*ZOOM TRANSFER SCOPE and Z.T.S. are trademarks of Bausch \& Lomb incorporated for graphical data transter instruments.

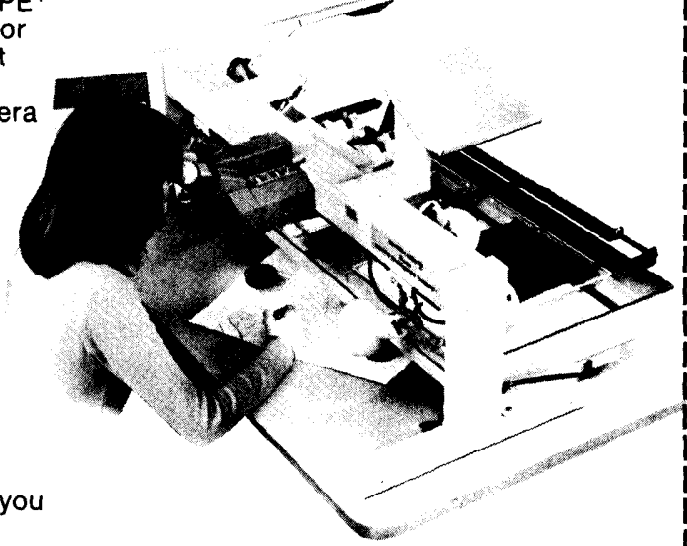

BAUSCH \& LOMB $\bigcirc$ Scientific Optical Products Division ROCHESTER, NEW YORK 14602 USA 716-338-6000, TWX 510-253-6189 TELEX 97-8231, CABLE: BAUSCH \& LOMB

In Canada: Bausch \& Lomb Canada, Ltd. Scientific Optical Products Division, 2001 Leslie Street, Don Mills, Ontario, Canada M3B 2MS 